\title{
PRODUCTIVE PERFORMANCE, IMMUNE STATUS AND METABOLIC ACTIVITY OF SUCKLING BOVINE CALVES TREATED WITH NIGELLA SATIVA OIL
}

\author{
ABD EL-HAFEEZ, A. M. ${ }^{1}$, M. A. E. ALI ${ }^{1}$, M. A. ABU EL-HAMD' ${ }^{1}$, A. A. WAHBA ${ }^{2}$ \\ and KAMLA M. EL-SAYED ${ }^{2}$
}

1. Animal Production Research Institute, ARC, Ministry of Agriculture, Dokki, Giza, Egypt.

2. Animal Health Research Institute, ARC, Ministry of Agriculture, Dokki, Giza, Egypt.

(Manuscript received 2 October 2014)

\begin{abstract}
The present study was conducted to investigate the effect of using Nigella sativa oil on the health of suckling calves, mortality, growth performance and Eimeria species infection through haematological, biochemical parameters, immune status and faecal examination during conventional and early weaning systems. For these purposes, twenty five newly born Friesian calves were randomly divided into five groups (5 in each); the first group suckled individually on milk for 15 weeks of age until weaning (conventional weaning) without treatment (S15T0), second group suckled for 15 weeks until weaning and received daily $0.06 \mathrm{ml}$ of Nigella sativa oil / Kg body weight for 15 weeks (S15T15), third group suckled for 7 weeks (early weaning) without treatment (S7T0), fourth and fifth groups (S7T15 and S7T7) suckled for 7 weeks and treated with the same dose of Nigella sativa oil for 15 and 7 weeks respectively. The results showed that all calves received Nigella sativa oil did not show symptoms of diarrhea and no animals died during the period of the experiment. On the other hand, the calves which did not receive Nigella sativa oil showed cases of diarrhea and 3 calves died. Also, calves treated with Nigella sativa oil (S15T15, S7T15 and S7T7) clearly showed increase $(P<0.05)$ of haemoglobin concentrations, haematocrit values, white blood cells counts, globulin, IgG and IgM concentrations than non-treated calves (S15T0 and S7T0). On the contrary, serum glucose and total lipids concentrations were decreased $(P<0.05)$ in treated groups, while serum total protein concentrations slightly increased $(P>0.05)$ in treated groups compared to non-treated ones. Insignificant differences $(P>0.05)$ among different groups were observed in concentrations of AST and ALT, which were in the normal range. The mean number of Eimeria sp. oocysts decreased in treated groups compared with non-treated ones. In parallel, slowdown of body weight gain was observed in calves treated with Nigella sativa oil compared to nontreated ones. It could be concluded that the use of Nigella sativa oil for suckling calves was effective in maintaining blood homeostasis, improving general health status and for prevention and treatment of health problems in suckling Friesian calves.
\end{abstract}

Keywords: Nigella sativa oil; Friesian calves; haematological; biochemical; immune; Eimeria; growth. 


\section{INTRODUCTION}

Interest of medicinal plants has burgeoned due to increased efficacy of new plant-derived drugs and the growing interest in natural products. Because of the concerns about the side effects of conventional medicine, the use of natural products as an alternative to conventional treatment in prevention and treatment of various diseases has been on the rise in the last few decades. Large numbers of these plants and their isolated constituents have shown beneficial therapeutic effects, including anti-oxidant, anti-inflammatory, anti-cancer, anti-microbial, anti-parasitic and immunomodulatory effects. Among the promising medicinal plants, Nigella sativa, a dicotyledon of the family Ranunculaceae, is an amazing herb with a rich historical and religious background. It is the black seed referred to by the prophet Mohammed as having healing powers. Nigella sativa seed is a complex substance of more than 100 compounds, some of which have not yet been identified or studied. A combination of fatty acids, volatile oils and trace elements are believed to contribute to its effectiveness. It has been shown to contain more than $30 \%(\mathrm{w} / \mathrm{w})$ of fixed oils with $85 \%$ of total unsaturated fatty acids (Houghton et. al., 1994).

The World Health Organization encourages using of medicinal herbs and plants to substitute or minimize the use of chemicals through the global trend to go back to nature (Allam et. al., 1999). The oil of Nigella sativa is used commonly in the Middle East as a traditional medicine to treat a variety of health problems. It has been used to treat a variety of disorders such as hypertension, diabetes, respiratory problems, stomach and intestinal complaints, kidney and liver function, and circulatory and immune system support. Its value has been assessed in numerous studies (Zaoui et. al., 2002, Meral et. al., 2004, and Khattab et. al., 2011). Deyab and Laji (2007) and Baghdadi and Al-Mathal (2011) found that Nigella sativa seeds were effective in treatment of $E$. tenella in chicks and Eimeria stieddae in rabbits respectively.

Critical period for the care and upbringing of calves is from birth until weaning where increasing health problems and mortality. The economic losses associated with the neonatal diseases in calves are alarmingly high. Gastro-enteritis and respiratory infections are the most serious pathological disorders implicated with such losses, particularly during the first period of life, when the immune system is incompatible enough against the vast array of causative pathogens (El-Bordeny, 2006).

Therefore, the objective of this study was to investigate the efficacy of Nigella sativa oil during conventional and early weaning systems to avoid health problems and mortality. In this regard, the effects of Nigella sativa oil on haematological, 
biochemical parameters, immune status, growth performance and coccidial infection in Friesian calves were studied.

\section{MATERIALS AND METHODS}

This study was carried out at Sakha Experimental Station, belonged to Animal Production Research Institute. Chemical analysis of blood samples and faecal examination were executed at Chemistry and Lack of Food and Toxins and Parasitology Departments of Animal Health Research Institute.

\section{Preparation of Nigella Sativa Oil Extract:}

The Nigella sativa seeds were powdered mechanically. The extract was obtained by cold shocking of the powdered seeds in $3 \times 1.5 \mathrm{I}$ of hexane during $3 \times 24 \mathrm{~h}$. The solvent was removed from the extract under reduced atmospheric pressure. The obtained oily extract from Nigella sativa seeds has a chestnut colour and agreeable perfume (Zaoui et. al., 2002).

\section{Experimental Animals and Treatment:}

Twenty five Friesian calves were used in this study. During the first three days of calves' life, they were fed individually on colostrum at a rate of $10 \%$ of body weight given in two meals. The calves were randomly divided at fourth day of age into five groups (5 in each).

The first and second groups were fed individually on milk at a rate of $10 \%$ of body weight given in two meals for six weeks. The milk allowances were reduced gradually until weaning at 15 weeks of age (conventional weaning). The first group (S15T0) did not treat with Nigella sativa oil. The calves of the second group (S15T15) received $0.06 \mathrm{ml} / \mathrm{Kg}$ body weight Nigella sativa oil daily by oral route (force-feeding) for 15 weeks.

The other three groups were fed individually on milk at a rate of $10 \%$ of body weight given in two meals for four weeks. After that, the milk allowances were reduced gradually until weaning at 7 weeks of age (early weaning). The third group did not treat with Nigella sativa oil (S7T0). Fourth and fifth groups (S7T15 and S7T7) included calves received daily the same previous dose of Nigella sativa oil (forcefeeding) for 15 and 7 weeks respectively.

Calf starter and hay were available in front of calves from the beginning of third week of age. Body weights were measured at birth, 7th and 15th week of age.

\section{Blood Sampling and Analysis:}

Blood samples were collected from jugular vein of calves at first week and then biweekly intervals until 15 weeks of age. Blood samples were collected in tubes 
containing EDTA (Ethylene diamine tetra acetic acid) as anticoagulant at each sampling time for determination of haemoglobin concentration, haematocrit value and white blood cells (WBCs) count. The concentration of haemoglobin $(\mathrm{Hb}, \mathrm{g} / \mathrm{dl})$ in the blood was determined colorimetrically by the method based on formation of syanomet haemoglobin as described by Bauer (1970). Haematocrit value $(\mathrm{Ht}, \%)$ was determined using microcapillary tubes with a micro haematocrit centrifuge at a rate of 12000 r.p.m. for 7 minutes. The different types of WBCs were also counted. Both white blood cells count using Bright-Line Hemocytometer and differential leukocytic count were described according to Dacie and Lewis (1984).

Serum samples were stored at $-20^{\circ} \mathrm{C}$ until analysis. Determination of levels of immunoglobulins (IgG and IgM) was done by bovine IgG and IgM ELISA kits according to the procedure outlined by manufacturer (Alpha Diagnostic International, Texas, USA and Kamiya Biomedical Company, Seattle, Washington, USA, respectively). Concentrations of glucose $(\mathrm{mg} / \mathrm{dl})$, total lipids $(\mathrm{mg} / \mathrm{dl})$, total protein $(\mathrm{g} / \mathrm{dl})$ and albumin $(\mathrm{g} / \mathrm{dl})$ in blood plasma were calculated according to the procedures described by the manufacturer (Biodiagnostic, Dokki, Giza, Egypt). Alanine aminotransferase and aspartate aminotransferase calculated according to manufacturer of Vito Scient, Heliopolis, Cairo, Egypt. Determination methods were colorimetric using spectrophotometer. Globulin level $(\mathrm{g} / \mathrm{dl})$ was calculated as the difference between total protein and albumin. The albumin/globulin ratio (A:G ratio) was calculated by dividing each albumin value by its corresponding globulin value.

\section{Faecal Sampling, Oocysts Count and Identification:}

Faecal samples were collected from calves in plastic bags at first week and then biweekly intervals until 15th week of age. The samples were examined by concentration flotation technique. The mean numbers of Eimeria species oocysts per one gram faeces collected from calves of different groups were counted by Mc-Master slide. Eimeria sp. oocysts were sporulated at room temperature and then identified according to Levine (1985).

\section{Statistical Analysis:}

Data were statistically analyzed using the general linear model procedure (SAS, 2002). Significance among the means was checked using Duncan's Multiple Range Test (Duncan, 1955). Probability values $\leq 5 \%$ were considered significant. 


\section{RESULTS AND DISCUSSION}

\section{Effect of Nigella Sativa Oil on Animal Health:}

Table (1) illustrates the effect of Nigella sativa oil treatment for different periods on animal health during conventional and early weaning systems of Friesian calves. All calves received Nigella sativa oil did not show symptoms of diarrhea and no animals died during the period of the experiment. The group of calves weaned at the age of 15 weeks and did not receive Nigella sativa oil (S15T0) showed 4 cases of diarrhea. They treated with anti-diarrhea drugs, (Scourban Plus and Diakur Plus according to the procedure described by the manufacturer). Two calves died at the age of 44 and 54 days and the other two calves were healed. In the group of calves that weaned at the age of 7 weeks and did not receive Nigella sativa oil (S7T0), 3 cases had diarrhea and treated with the same anti-diarrhea drugs. One calf died at the age of 38 days and the other two calves healed.

Table 1. Effect of Nigella sativa oil treatment on animal health for different periods during conventional and early weaning systems of Friesian calves.

\begin{tabular}{|l|c|c|c|c|c|}
\hline \multirow{2}{*}{ Item } & \multicolumn{5}{|c|}{ Groups } \\
\cline { 2 - 6 } & S15T0 & S15T15 & S7T0 & S7T15 & S7T7 \\
\hline Diarrhea incidence rate & $4 / 5$ & $0 / 5$ & $3 / 5$ & $0 / 5$ & $0 / 5$ \\
\hline Mortality rate & $2 / 5$ & $0 / 5$ & $1 / 5$ & $0 / 5$ & $0 / 5$ \\
\hline
\end{tabular}

S15T0 = Suckling for 15 weeks and no treatment, S15T15 = Suckling for 15 weeks and treatment for 15 weeks, S7T0 = Suckling for 7 weeks and no treatment, S7T15 = Suckling for 7 weeks and treatment for 15 weeks, and S7T7 = Suckling for 7 weeks and treatment for 7 weeks.

\section{Effect of Nigella Sativa Oil on Haematological Parameters:}

Table (2) illustrates the effect of Nigella sativa oil treatment for different periods on haemoglobin concentrations and haematocrit values during conventional and early weaning systems of Friesian calves. It is clearly shows that the haemoglobin concentrations and haematocrit values in the treated calves with Nigella sativa oil (S15T15, S7T15 and S7T7) were higher $(P<0.05)$ than non-treated calves (S15T0 and S7T0). It also shows that the haemoglobin concentrations and haematocrit values were significantly higher $(\mathrm{P}<0.05)$ in the treated calves for 15 weeks (S15T15 and S7T15) than calves treated for 7 weeks (S7T7). Haemoglobin concentrations and haematocrit values for the group that weaned at 15 weeks (S15T0) were high when compared to the group weaned at 7 weeks (S7T0) but this insignificantly higher. These results agreed with that reported by Zaoui et. al. (2002) who found increased haemoglobin concentration in plasma when rats treated with Nigella sativa fixed oil. Also, these are in harmony with those reported by Ismail et. al. (2003) and Khattab et. al. (2011) who reported that, the improvement of haematological traits observed 
in the treated groups by Nigella sativa oil may be due to improvement in immune system responsiveness. Nigella sativa contains $\mathrm{Zn}, \mathrm{Cu}, \mathrm{Mn}, \mathrm{Mg}$, Se and some vitamins such as C, A, E and folic acid which have a role in enhancing immune system. Folic acid, Fe and vitamin $\mathrm{C}$ have roles in red blood cell formation, maturation and in the biosynthesis, absorption and utilization. These results indicate that Nigella sativa oil had the ability to increase haemoglobin and haematocrit levels significantly in the treated groups and this could be the reason to improve the haemoglobin and haematocrit levels in these groups.

Table 2. Effect of Nigella sativa oil treatment for different periods on haematological parameters during conventional and early weaning systems of Friesian calves (mean \pm S.E.).

\begin{tabular}{|c|c|c|c|c|c|}
\hline \multirow{2}{*}{$\begin{array}{l}\text { Haematological } \\
\text { parameters }\end{array}$} & \multicolumn{5}{|c|}{ Groups } \\
\hline & S15T0 & S15T15 & S7T0 & S7T15 & S7T7 \\
\hline $\begin{array}{l}\text { Haemoglobin } \\
(\mathrm{g} / \mathrm{dl})\end{array}$ & $10.03 \pm 1.17^{d}$ & $11.77 \pm 0.91^{\mathrm{a}}$ & $9.64 \pm 1.18^{\mathrm{d}}$ & $11.26 \pm 1.10^{\mathrm{b}}$ & $10.56 \pm 0.96^{c}$ \\
\hline Haematocrit (\%) & $30.41 \pm 1.50^{c}$ & $36.37 \pm 2.18^{\mathrm{a}}$ & $31.05 \pm 1.72^{\mathrm{c}}$ & $35.81 \pm 2.12^{\mathrm{a}}$ & $33.28 \pm 1.92^{b}$ \\
\hline WBCs $\left(x 10^{3} / \mu \mathrm{l}\right)$ & $6.562 \pm 0.364^{c}$ & $7.722 \pm 0.428^{a}$ & $6.427 \pm 0.461^{\mathrm{c}}$ & $7.643 \pm 0.362^{\mathrm{a}}$ & $7.057 \pm 0.371^{b}$ \\
\hline Neutrophils (\%) & $41.28 \pm 1.68^{c}$ & $44.90 \pm 2.88^{\mathrm{a}}$ & $40.40 \pm 3.26^{c}$ & $45.30 \pm 3.18^{\mathrm{a}}$ & $42.84 \pm 3.19^{b}$ \\
\hline Basophils (\%) & $0.24 \pm 0.06$ & $0.25 \pm 0.06$ & $0.26 \pm 0.05$ & $0.26 \pm 0.04$ & $0.25 \pm 0.04$ \\
\hline Eosinophils (\%) & $1.68 \pm 0.35$ & $1.65 \pm 0.23$ & $1.71 \pm 0.21$ & $1.67 \pm 0.25$ & $1.67 \pm 0.20$ \\
\hline Lymphocytes (\%) & $53.40 \pm 2.26^{\mathrm{a}}$ & $50.49 \pm 2.87^{c}$ & $54.33 \pm 3.25^{\mathrm{a}}$ & $50.17 \pm 3.16^{c}$ & $52.74 \pm 3.33^{b}$ \\
\hline Monocytes (\%) & $3.40 \pm 1.49^{\mathrm{a}}$ & $2.70 \pm 0.28^{\mathrm{b}}$ & $3.3 \pm 0.41^{\mathrm{a}}$ & $2.60 \pm 0.45^{\mathrm{b}}$ & $2.50 \pm 0.43^{b}$ \\
\hline
\end{tabular}

abc: Means in the same row with different superscripts are significantly different $(P<0.05)$.

S15T0 = Suckling for 15 weeks and no treatment, S15T15 = Suckling for 15 weeks and treatment for 15 weeks, S7T0 $=$ Suckling for 7 weeks and no treatment, S7T15 = Suckling for 7 weeks and treatment for 15 weeks, and S7T7 = Suckling for 7 weeks and treatment for 7 weeks.

Nigella sativa oil treatment increased significantly $(P<0.05)$ the white blood cells count in the three treated groups (S15T15, S7T15 and S7T7) compared to nontreated ones (S15T0 and S7T0). This increase was significantly higher $(P<0.05)$ in treated groups for 15 weeks (S15T15 and S7T15), than those treated for 7 weeks (S7T7). While there was no significant effect of the length of the suckling period on white blood cells count, there is no difference between groups S15T15 and S7T15, and also there is no significant difference between groups S15T0 and S7T0. These results agreed with Meral et. al. (2004) who found that, significant increase of white blood cells count of diabetic rabbits treated with Nigella sativa oil. Also, it agreed with 
Al-Kudsi et. al. (2008) who did not find significant effect on length of the suckling period on white blood cells count.

Table (2) shows the effect of nigella sativa oil treatment for different periods on the differential white blood cells \% during conventional and early weaning systems of Friesian calves. In general, the percentage of neutrophils increased significantly in the treated groups (S15T15, S7T15 and S7T7), which is considered the first line of defense in the body against bacterial infection. This result indicated that Nigella sativa oil treatment might increase the defense mechanism of the body against bacterial infections. Lymphocytes showed reverse direction where decreased significantly in the treated groups when compared with non-treated ones. There was also no effect of length of the suckling period on the percentage of white blood cells count. These percentages were within the same that indicated by El-Gaafrawy et. al. (2000).

\section{Effect of Nigella Sativa Oil on Biochemical Parameters of Blood Serum:}

Nigella sativa oil treatment decreased the glucose concentrations significantly $(\mathrm{P}<0.05)$ in the treated calves (S15T15, S7T15 and S7T7) compared to the nontreated ones (S15T0 and S7T0); but they were in normal range (Table 3). These agreed with Zaoui et. al. (2002) who reported a significant decrease in serum glucose level in rats when treated with Nigella sativa fixed oil compared to the control placebo rats. Concentration of plasma glucose was significantly low $(P<0.05)$ in calves weaned early (S7T0, S7T15 and S7T7) compared to the calves weaned conventionally (S15T0). Calves that weaned late were fed milk and consumed only small amounts of calf starter. The significant differences in glucose concentration may be attributed to calf's rumen of groups (S7T0, S7T15 and S7T7), which are more develop than that of group S15T0, which led to increase dependence on VFA's, consequently decreased blood glucose. This agreed with those reported by Quigley et. al. (1991).

Table (3) illustrates the effect of Nigella sativa oil treatment for different periods on serum total protein during conventional and early weaning systems of Friesian calves. Data showed insignificant increase in serum total protein $(P>0.05)$ for treated groups compared to non-treated ones either in the conventional weaning groups or early weaning groups. In the same time, serum total protein concentration significantly increased in the early weaning groups compared to the conventional weaning ones. This may be attributed to the increased feed intake of calves that weaned early. The present values of serum total protein are within the normal range and are in good agreement with those obtained by several investigators (Al-Kudsi et. al., 2008 and Lee et. al., 2008). Insignificant differences were observed in blood serum albumin concentration of calves among the different groups (Table 3). 
Table 3. Effect of Nigella sativa oil treatment for different periods on biochemical parameters of blood serum during conventional and early weaning systems of Friesian calves (mean \pm S.E.).

\begin{tabular}{|l|c|c|c|c|c|}
\hline \multirow{2}{*}{ Item } & \multicolumn{5}{|c|}{ Groups } \\
\cline { 2 - 6 } & S15T0 & S15T15 & S7T0 & S7T15 & S7T7 \\
\hline Glucose (mg/dl) & $78.51 \pm 4.37^{\mathrm{a}}$ & $70.87 \pm 6.50^{\mathrm{c}}$ & $74.38 \pm 5.92^{\mathrm{b}}$ & $62.13 \pm 4.64^{\mathrm{e}}$ & $67.07 \pm 4.31^{\mathrm{d}}$ \\
\hline Total protein (g/dl) & $6.73 \pm 1.00^{\mathrm{b}}$ & $6.90 \pm 0.86^{\mathrm{b}}$ & $7.12 \pm 090^{\mathrm{a}}$ & $7.25 \pm 0.88^{\mathrm{a}}$ & $7.21 \pm 0.65^{\mathrm{a}}$ \\
\hline Albumin (g/dl) & $3.22 \pm 0.85$ & $3.10 \pm 0.68$ & $3.67 \pm 0.67$ & $3.25 \pm 0.93$ & $3.38 \pm 0.67$ \\
\hline Globulin (g/dl) & $3.52 \pm 0.76^{\mathrm{b}}$ & $3.80 \pm 0.53^{\mathrm{a}}$ & $3.44 \pm 0.64^{\mathrm{b}}$ & $4.00 \pm 0.58^{\mathrm{a}}$ & $3.82 \pm 0.46^{\mathrm{a}}$ \\
\hline A:G ratio & $0.97 \pm 0.38^{\mathrm{a}}$ & $0.83 \pm 0.23^{\mathrm{b}}$ & $1.10 \pm 0.29^{\mathrm{a}}$ & $0.84 \pm 0.31^{\mathrm{b}}$ & $0.90 \pm 0.23^{\mathrm{b}}$ \\
\hline & & & & & \\
Total lipid (mg/dl) & $211.50 \pm 16.35^{\mathrm{b}}$ & $185.76 \pm 15.29^{\mathrm{d}}$ & $229.23 \pm 18.00^{\mathrm{a}}$ & $196.12 \pm 15.81^{\mathrm{c}}$ & $216.94 \pm 18.30^{\mathrm{b}}$ \\
\hline AST (unit/L) & $52.75 \pm 7.29$ & $54.96 \pm 7.29$ & $53.13 \pm 6.87$ & $50.82 \pm 9.21$ & $54.94 \pm 9.35$ \\
\hline ALT (unit/L) & $14.39 \pm 5.55$ & $13.99 \pm 3.79$ & $12.64 \pm 4.03$ & $13.23 \pm 3.30$ & $13.30 \pm 3.59$ \\
\hline
\end{tabular}

abc: Means in the same row with different superscripts are significantly different $(P<0.05)$.

S15T0 = Suckling for 15 weeks and no treatment, S15T15 = Suckling for 15 weeks and treatment for 15 weeks, S7T0 $=$ Suckling for 7 weeks and no treatment, S7T15 = Suckling for 7 weeks and treatment for 15 weeks, and S7T7 = Suckling for 7 weeks and treatment for 7 weeks.

Table (3) shows that there were significantly high differences in the blood serum globulin concentrations in the treated calves with Nigella sativa oil when compared to non-treated ones. This attributed to high concentration of antibodies in the treated calves. It also noted that there was no significant difference of globulin concentration in calves treated for 15 weeks compared to that treated for 7 weeks only. There was no significant effect of length of the suckling period on globulin concentration. The observed increase in globulin concentrations in case of treated calves may represent responsive mechanism enhancing the immunity of the host.

There was significant decrease of $A: G$ ratio between treated and non-treated groups. This significant decrease in the A:G ratio was related to the change in globulin concentrations not to albumin concentrations.

There was a significant difference of Nigella sativa oil treatment on total lipids concentration of blood serum, where the lowest values $(P<0.05)$ were recorded by the treated groups while the highest values were recorded by the non-treated ones.

Also, there was a significant effect of length of the suckling period on total lipids concentration of blood serum, where there were higher concentrations $(P<0.05)$ in the suckled groups for 7 weeks compared with concentrations recorded in the suckled groups for 15 weeks. This may be due to the development of the rumen which more efficient in calves that weaned early when compared to calves weaned 
late. These results agreed with that reported by Zaoui et. al. (2002), who found that there was decrease in serum total lipid level when rats treated with Nigella sativa oil fixed.

Insignificant differences $(P>0.05)$ among the different groups were observed in concentrations of aspartate aminotransferase (AST) and alanine aminotransferase (ALT). These results indicated that Nigella sativa oil treatment had no effect on activity of enzymes AST and ALT which mean no toxic effect on liver function, cardiac muscle and skeletal muscle (Bush, 1991). These results agreed with those obtained by Khattab et. al. (2011).

\section{Effect of Nigella Sativa Oil on Immunoglobulins in Blood Serum:}

Table (4) shows that, concentration of immunoglobulins (IgG and IgM) in the blood serum increased significantly $(P<0.05)$ in both treated groups. It is clearly noted that the immunoglobulins were significantly higher $(P<0.05)$ in groups treated for 15 weeks compared with that treated for 7 weeks. No significant effect of the length of the suckling period on the concentration of immunoglobulins, where the level of concentrations of immunoglobulins (IgG and IgM) were higher in groups suckled for 15 weeks compared with that suckled for 7 weeks, but this increase insignificant.

These results may be related to the role of the antioxidants, where Nigella sativa oil contains a substance called Nigellone which is a natural antioxidant that can modulate and regulate the early activation steps in the acquired immune response. The aforementioned increase of immunoglobulins could be credited to B-lymphocyte stimulation. Consequently the immunoglobulins will elevate initiating an immune response through helper T-cell, cytotoxic T-cells and $\mathrm{CD}_{8}$-T-cell (Tizard, 1992 and ElGaafrawy et. al., 2000). This may lead to perfect calves immunocompetent.

Table 4. Effect of Nigella sativa oil treatment for different periods on immunoglobulins $(\mathrm{mg} / \mathrm{ml})$ in blood serum during conventional and early weaning systems of Friesian calves (mean \pm S.E.).

\begin{tabular}{|l|c|c|c|c|c|}
\hline \multirow{2}{*}{ Item } & \multicolumn{5}{|c|}{ Groups } \\
\cline { 2 - 6 } & S15T0 & S15T15 & S7T0 & S7T15 & S7T7 \\
\hline IgG (mg/ml) & $46.83 \pm 4.93^{\mathrm{c}}$ & $60.25 \pm 4.95^{\mathrm{a}}$ & $43.21 \pm 3.74^{\mathrm{c}}$ & $58.23 \pm 4.29^{\mathrm{a}}$ & $53.93 \pm 8.21^{\mathrm{b}}$ \\
\hline IgM (mg/ml) & $2.49 \pm 0.52^{\mathrm{c}}$ & $3.35 \pm 0.66^{\mathrm{a}}$ & $2.37 \pm 0.40^{\mathrm{c}}$ & $3.11 \pm 0.66^{\mathrm{a}}$ & $2.79 \pm 0.45^{\mathrm{b}}$ \\
\hline
\end{tabular}

abc: Means in the same row with different superscripts are significantly different $(P<0.05)$.

S15T0 = Suckling for 15 weeks and no treatment, S15T15 = Suckling for 15 weeks and treatment for 15 weeks, S7T0 = Suckling for 7 weeks and no treatment, S7T15 = Suckling for 7 weeks and treatment for 15 weeks, and S7T7 = Suckling for 7 weeks and treatment for 7 weeks. 


\section{Effect of Nigella Sativa Oil on Eimeria sp. Oocysts:}

Table (5) shows that the number of infected calves decreased in treated groups (S15T15, S7T15 and S7T7) compared with non-treated ones (S15T0 and S7T0) at the termination of experiment. Also, the mean number of Eimeria sp. oocysts count in faecal samples of calves decreased in treated groups compared with non-treated ones. The mean number of Eimeria sp. oocysts in group S15T15 decreased weekly until reached 50 oocysts per gram faecal samples in one calf at $13^{\text {th }}$ and $15^{\text {th }}$ weeks. Eimeria sp. oocysts could not be detected in faecal samples of calves in groups S7T15 and S7T7 at $13^{\text {th }}$ and $15^{\text {th }}$ weeks respectively. On the other hand, the non-treated groups (S15T0 and S7T0) showed that 3 and 4 calves still infected with the mean number of 1933 and 1575 Eimeria sp. oocysts respectively. The present results agreed with that of Deyab and Laji (2007) and Baghdadi and Al-Mathal (2011) who demonstrated a reduction in faecal oocysts of $E$. tenella in chicks and $E$. stiedae in rabbits treated with Nigella sativa seeds respectively.

Eimeria auburnensis and Eimeria zuernii sporulated oocysts (fig. 1 a and b) were identified in calves. Eimeria auburnensis sporulated oocysts were ovoid, somewhat flattened at the narrow end. The size ranged between 34-39 $\times 25-28 \mu \mathrm{m}$. They had a micropyle and polar granule and without a residuum. The sporulation time was 2-3 days. Eimeria zuernii sporulated oocysts were ovoid to sub-ovoid. The size ranged between $22-28 \times 16-20 \mu \mathrm{m}$. Neither micropyle nor a residuum were seen. The polar granule was present or not. The sporulation time was 2-5 days.

Table 5. Mean numbers of Eimeria sp. oocysts per one gram faeces in different groups of non-treated and treated calves with Nigella sativa oil during conventional and early weaning systems.

\begin{tabular}{|c|c|c|c|c|c|c|c|c|c|c|}
\hline \multirow[b]{3}{*}{$\begin{array}{l}\text { Duration } \\
\text { in weeks }\end{array}$} & \multicolumn{10}{|c|}{ Groups } \\
\hline & \multicolumn{2}{|c|}{ S15T0 } & \multicolumn{2}{|c|}{ S15T15 } & \multicolumn{2}{|c|}{ S7T0 } & \multicolumn{2}{|c|}{ S7T15 } & \multicolumn{2}{|c|}{ S7T7 } \\
\hline & $\begin{array}{c}\text { No. of } \\
\text { infected } \\
\text { calves }\end{array}$ & $\begin{array}{c}\text { Mean } \\
\text { No. of } \\
\text { oocysts } \\
*\end{array}$ & $\begin{array}{c}\text { No. of } \\
\text { infected } \\
\text { calves }\end{array}$ & $\begin{array}{c}\text { Mean } \\
\text { No. of } \\
\text { oocysts } \\
*\end{array}$ & $\begin{array}{l}\text { No. of } \\
\text { infected } \\
\text { calves }\end{array}$ & $\begin{array}{l}\text { Mean No. } \\
\text { of } \\
\text { oocysts* }\end{array}$ & $\begin{array}{l}\text { No. of } \\
\text { infected } \\
\text { calves }\end{array}$ & $\begin{array}{c}\text { Mean } \\
\text { No. of } \\
\text { oocysts } \\
*\end{array}$ & $\begin{array}{l}\text { No. of } \\
\text { infected } \\
\text { calves }\end{array}$ & $\begin{array}{l}\text { Mean } \\
\text { No. of } \\
\text { ocysts* }\end{array}$ \\
\hline $1^{\text {st }} w k$ & 0 & 0 & 0 & 0 & 0 & 0 & 0 & 0 & 0 & 0 \\
\hline $3^{\text {rd }} w k$ & 2 & 480 & 0 & 0 & 2 & 660 & 1 & 120 & 2 & 200 \\
\hline $5^{\text {th }} \mathrm{wk}$ & 3 & 600 & 2 & 1550 & 5 & 336 & 3 & 1353 & 3 & 583 \\
\hline $7^{\text {th }} w k$ & 4 & 550 & 4 & 3175 & 4 & 460 & 5 & 544 & 2 & 90 \\
\hline $9^{\text {th }} w k$ & 3 & 683 & 1 & 800 & 4 & 900 & 3 & 113 & 3 & 73 \\
\hline $11^{\text {th }} w \mathrm{k}$ & 3 & 1517 & 1 & 600 & 4 & 1125 & 1 & 80 & 3 & 133 \\
\hline $13^{\text {th }} w k$ & 3 & 1733 & 1 & 50 & 4 & 1075 & 0 & 0 & 1 & 300 \\
\hline $15^{\text {th }} w \mathrm{k}$ & 3 & 1933 & 1 & 50 & 4 & 1575 & 0 & 0 & 0 & 0 \\
\hline
\end{tabular}

S15T0 = Suckling for 15 weeks and no treatment, S15T15 = Suckling for 15 weeks and treatment for 15 weeks, S7T0 = Suckling for 7 weeks and no treatment, S7T15 = Suckling for 7 weeks and treatment for 15 weeks, and S7T7 = Suckling for 7 weeks and treatment for 7 weeks.

*Mean number of oocysts calculated per one gm faeces. 


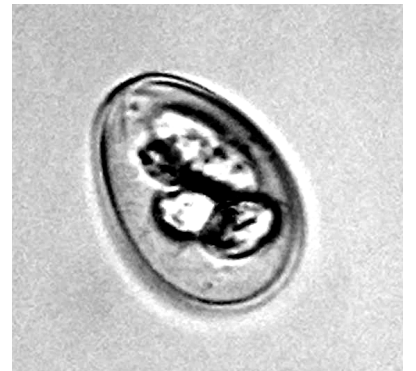

Fig. (1a). Eimeria auburnensis

sporulated oocyst, X 400

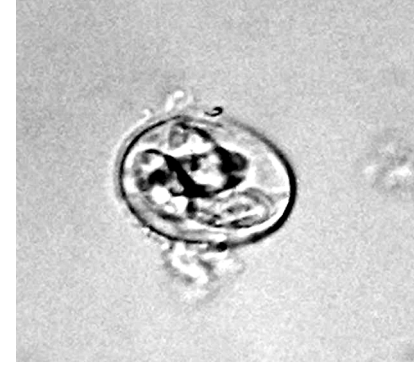

Fig. (1b). Eimeria zuernii

sporulated oocyst, X 400

\section{Effect of Nigella Sativa Oil on Body Weight:}

Table (6) illustrates the evolution of the means body weight and daily weight gain of the Nigella sativa oil treated groups and non-treated ones. The progression of body weight was not similar in all groups. Indeed, the Nigella sativa oil treated calves had lower body weights and daily weight gain than that of non-treated calves counterparts.

Such effect on weight of calves was described by Zaoui et. al. (2002), who observed significant slowdown of body weight evolution in Nigella sativa fixed oil treated rats comparatively to rats in control group. The slowdown of body weight evolution in Nigella sativa oil treated calves might be related to the decrease of serum total lipids and glucose levels as a consequence of a possible reduction in feed intake by the drug administration. Other explanations are also possible.

The daily weight gain in the early weaned groups after 7 weeks of age decreased and this may be as a result of the weaning shock.

Table 6. Effect of Nigella sativa oil treatment for different periods on body weight evolution during conventional and early weaning systems of Friesian calves (mean \pm S.E.).

\begin{tabular}{|l|l|l|l|l|l|}
\hline \multirow{2}{*}{ Item } & \multicolumn{5}{|c|}{ Groups } \\
\cline { 2 - 6 } & \multicolumn{1}{|c|}{ S15T0 } & S15T15 & S7T0 & S7T15 & S7T7 \\
\hline Birth weight (Kg) & $28.50 \pm 5.32$ & $27.80 \pm 3.77$ & $30.00 \pm 5.24$ & $29.60 \pm 3.64$ & $28.70 \pm 5.52$ \\
\hline $\begin{array}{l}\text { Weight at 7 weeks } \\
\text { (Kg) }\end{array}$ & $50.75 \pm 4.27$ & $45.40 \pm 4.51$ & $50.70 \pm 6.46$ & $53.25 \pm 5.98$ & $48.30 \pm 7.65$ \\
\hline $\begin{array}{l}\text { Daily weight gain } \\
\text { until 7 weeks (Kg) }\end{array}$ & $0.472 \pm 0.042$ & $0.359 \pm 0.114$ & $0.422 \pm 0.105$ & $0.485 \pm 0.069$ & $0.400 \pm 0.081$ \\
\hline $\begin{array}{l}\text { Weight at 15 weeks } \\
\text { (Kg) }\end{array}$ & $85.00 \pm 8.53^{\mathrm{a}}$ & $75.30 \pm 6.25^{\mathrm{ab}}$ & $69.40 \pm 4.83^{\mathrm{b}}$ & $79.75 \pm 11.06^{\mathrm{ab}}$ & $73.30 \pm 7.55^{\mathrm{ab}}$ \\
\hline $\begin{array}{l}\text { Daily weight gain } \\
\text { from birth until 15 } \\
\text { weeks (Kg) }\end{array}$ & $0.560 \pm 0.028^{\mathrm{a}}$ & $0.452 \pm 0.082^{\mathrm{bc}}$ & $0.375 \pm 0.046^{\mathrm{c}}$ & $0.479 \pm 0.072^{\mathrm{ab}}$ & $0.425 \pm 0.072^{\mathrm{bc}}$ \\
\hline
\end{tabular}

abc: Means in the same row with different superscripts are significantly different $(P<0.05)$.

S15T0 = Suckling for 15 weeks and no treatment, S15T15 = Suckling for 15 weeks and treatment for 15 weeks, S7T0 = Suckling for 7 weeks and no treatment, S7T15 = Suckling for 7 weeks and treatment for 15 weeks, and S7T7 = Suckling for 7 weeks and treatment for 7 weeks. 


\section{CONCLUSION}

The results obtained from this study clearly showed that, Nigella sativa oil treatment to suckling Friesian calves was effective in maintaining blood homeostasis as it contains natural antioxidants. In addition, it improved the general health status as a result of increased immune response. Treatment for 15 weeks was better in terms of haematological and immune responses than treatment for 7 weeks, whether conventional or early weaning systems. Also, Nigella sativa oil has a positive impact in treating Eimeria sp. infection. It has been concluded that Nigella sativa oil could be used for prevention and treatment of health problems in suckling Friesian calves.

\section{REFERENCES}

1. Al-kudsi, N. H., A. Sh. Al-Kiasy and A. J. Al-Hadithy. 2008. Effect of restricted milk feeding for different periods on some blood attributes of Friesian female calves in Iraq. Egyptian Journal of Nutrition and Feeds, 11 (1): 229-243.

2. Allam S. M., H. M. El-Hosseiny, A. M. Abdel Gawad, S. A. El-Saadany, and A. M. M. Zeid. 1999. Medicinal herbs and plants as feed additives for ruminant. I. Effect of using some medicinal herbs and plants as feed additives on Zaraibi goat performance. Egyptian Journal of Nutrition and Feeds, 2: 349-365.

3. Baghdadi, H. B., and E. M. Al-Mathal. 2011. Anti-coccidial activity of Nigella sativa L. Journal of Food, Agriculture and Environment, 9 (2): 10-17.

4. Bauer, J. D. 1970. Haemoglobin. Part III. Hematology, in: Gradwoll clinical Laboratory and diagnosis. 17th ed. By Frankl's Reitman, s and Sonnen wirth, A. C., USA.

5. Bush, B. M. 1991. Interpretation of laboratory results for small animal clinicians. Oxford Blackwell Scientific Publications, London. pp. 225-299.

6. Dacie, S. J. V. and S. M. Lewis. 1984. Practicaal Haematology. 6th ed. Chuchill Livingstone, Edinbugh, London, Melbourne and New. York, pp.2.

7. Deyab, A. F., and N. M. Laji. 2007. Effect of Nigella sativa and Curcuma Longa on experimental Eimeria tenella infections in chicks. Egyptian Journal of Medical Microbiology, 16 (4): 583-591.

8. Duncan, D. B. 1955. Multiple ranges and multiple F. Test. Biometrics, 11: 1-24.

9. El-Bordeny, N. E. Y. 2006. Effect of some natural supplements on calves performance. Ph. D. Thesis, Faculty of Agriculture Ain Shams University.

10. El-Gaafrawy, A. M., N. Ahmed, M. K. El-Banna and I. L. Ibrahim. 2000. Effect of Selenium and vitamin E supplementation on immue response and performance of Baladi calves. Proc. Conf. Anim. Prod. In the 21th Century, Sakha, 18-20 April: 267-276. 
11. Houghton, P. J., R. Zarka, B. D. L. Heras, and J. R. S. Hoult. 1994. Fixed oil of Nigella sativa and derived thymoquinone inhibit eicosanoid generation in leukocytes and membrane lipid peroxidation. Planta Medica, 61: 33-36.

12. Ismail A. M., A. A. Sedki and A. G. Abdallah. 2003. Influence of black seed, garlic and onion supplementation on reproductive performance in rabbits. Egyptian. Journal of Agricultural Research, 81: 1193-1207.

13. Khattab, H. M., A. Z. El-Basiony, S. M. Hamdy, and A. A. Marwan. 2011. Immune response and productive performance of dairy buffaloes and their offspring supplemented with black seed oil. Iranian Journal of Applied Animal Science, 1 (4): 227-234.

14. Lee, H. J., M. A. Khan, W. S. Lee, H. S. Kim, K. S. Ki, S. J. Kang, T. Y. Hur, M. S. Khan and Y. J. Choi. 2008. Growth, blood metabolites, and health of Holstein calves fed milk replacer containing different amounts of energy and protein. Asian-Australasian Journal of Animal Sciences, 21 (2):198-203

15. Levine, N. D. 1985. Veterinary Protozoology. Iowa State University Press, Ames. 1st Ed.

16. Meral, I., N. Donmez, B. Baydas, F. Belge and M. Kanter. 2004. Effect of Nigella sativa L. on heart rate and some haematological values of alloxan-induced diabetic rabbits. Scandinavian Journal of Laboratory Animal Science, 31 (1): 4953.

17. Quigley, III, J. D., L. A. Caldwell, G. D. Sinks, and R. N. Heitmann. 1991. Changes in blood glucose, nonesterified fatty acids, and ketones in response to weaning and feed intake in young calves. Journal of Dairy Science, 74: 250-257.

18. SAS. 2002. User's Guide: Statistics, Version 9.0 Edition. SAS Institute Inc., Cary, NC, USA.

19. Tizard, I. 1992. Veterinary Immunology: An Introduction. 4th ed. London: W. B. Saunders Co., Philadelphia, PA.

20. Zaoui, A., Y. Cherrah, K. Alaoui, N. Mahassine, H. Amarouch, and M. Hassar. 2002. Effects of Nigella sativa fixed oil on blood homeostasis in rat. Journal of Ethnopharmacology, 79 (1): 23-26. 


\section{الأداء الإتتاجي ، الحالة المناعية و النشاط التمثيلي للعجول البقري الرضيعة المعاملة بزيت حبة البركة ولهاعة ولئة}

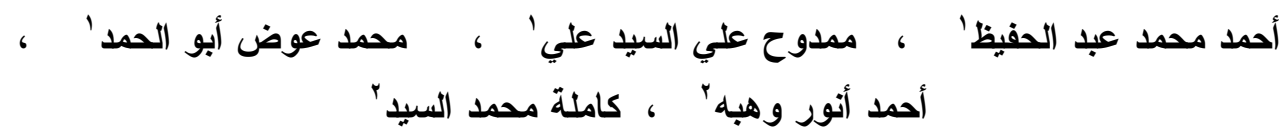

$$
\begin{aligned}
& \text { ا . . معهد بحوث الإنتاج الحيواني ، مركز البحوث الزراعية ، الدقى ، الجيزة ، مصر. }
\end{aligned}
$$

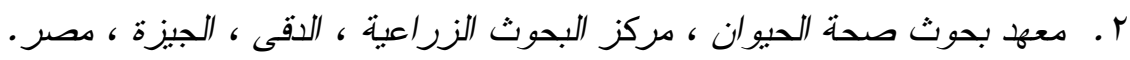

أجريت هذه الدر اسة لبحث نأثير استخدام زيت حبة البركة لتجنب المشاكل الصحية وإرتفــاع

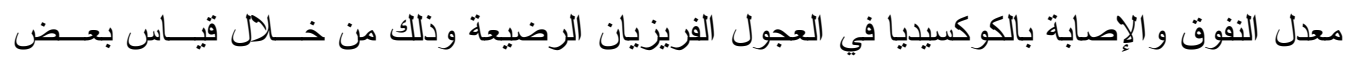

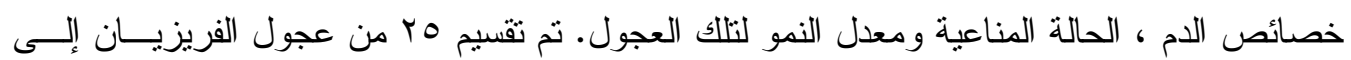

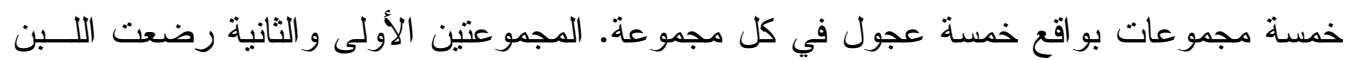

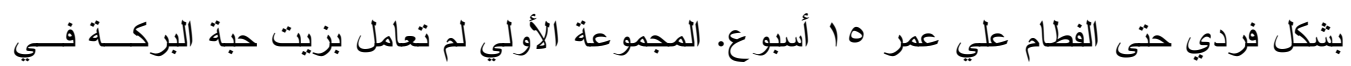

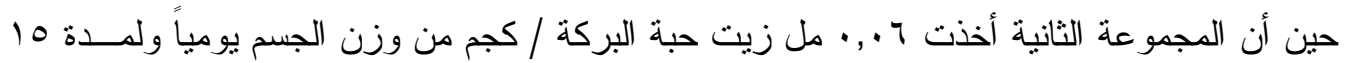
أسبوع. بينما الثلاثة مجموعات الأخرى رضعت اللبن بشكل فردي حتي الفطام علي عمر V أسابيع.

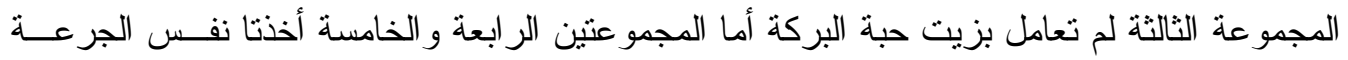
من زيت حبة البركة يومباً ولمدة 10 ، V أسبابيع على التو الي.

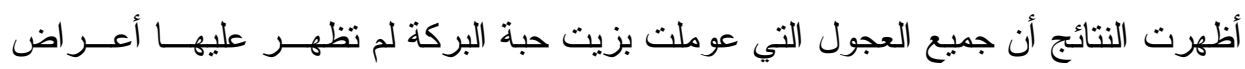

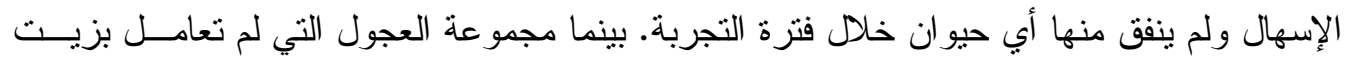

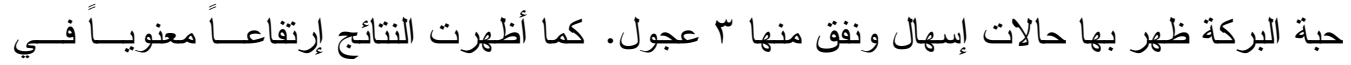

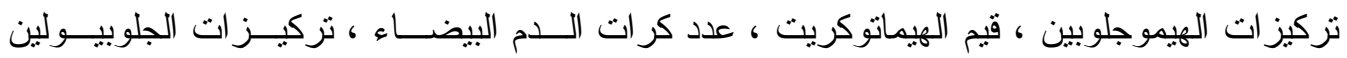
و الأجسام المناعية في مجموعات العجول المعاملة بزيت حبة البركة عند مقارنتها بالمجموعات التـي كئي

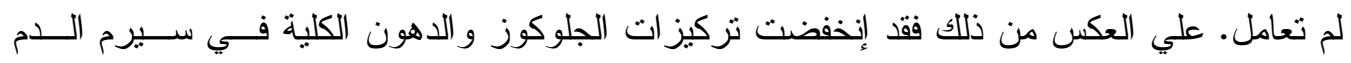

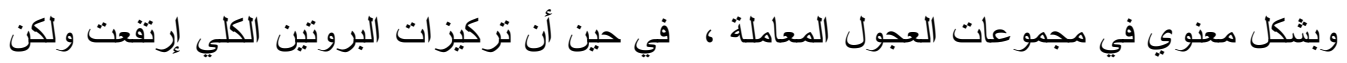

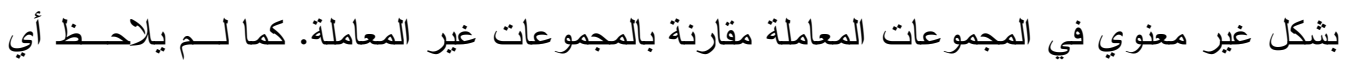

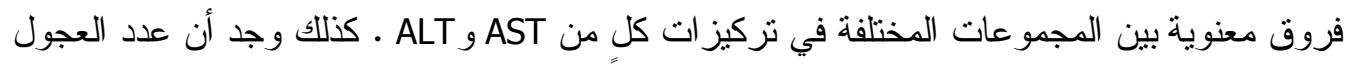

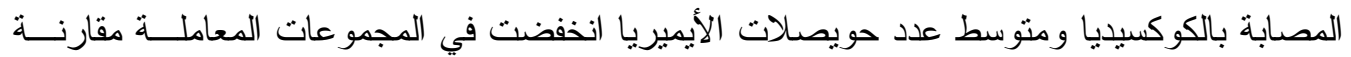

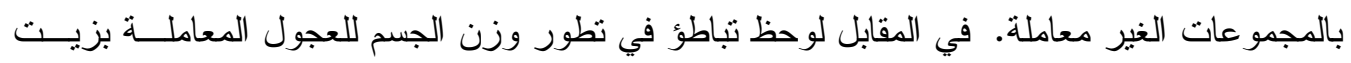
حبة البركة مقارنة بمجموعات العجول غير المعاملة.

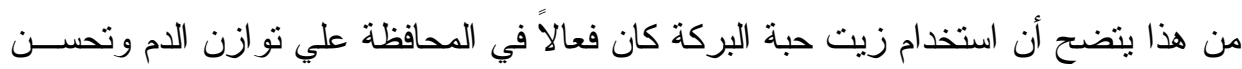
الحالة الصحية العامة وبناءً عليه ننصح باستخدام زيت حبة البركة للوقاية و العلاج للعديد من المشاكل الصحية لعجول أبقار الفريزيان الرضيعة. 